\title{
Angiotensin II enhances epithelial-to-mesenchymal transition through the interaction between activated hepatic stellate cells and the stromal cell-derived factor-1/CXCR4 axis in intrahepatic cholangiocarcinoma
}

\author{
KOICHI OKAMOTO ${ }^{1}$, HIDEHIRO TAJIMA ${ }^{1}$, SHINICHI NAKANUMA ${ }^{1}$, SEISHO SAKAI ${ }^{1}$, ISAMU MAKINO ${ }^{1}$, \\ JUN KINOSHITA ${ }^{1}$, HIRONORI HAYASHI ${ }^{1}$, KEISHI NAKAMURA ${ }^{1}$, KATSUNOBU OYAMA ${ }^{1}$, \\ HISATOSHI NAKAGAWARA ${ }^{1}$, HIDETO FUJITA ${ }^{1}$, HIROYUKI TAKAMURA ${ }^{1}$, ITASU NINOMIYA ${ }^{1}$, \\ HIROHISA KITAGAWA ${ }^{1}$, SACHIO FUSHIDA ${ }^{1}$, TAKASHI FUJIMURA ${ }^{1}$, SHINICHI HARADA ${ }^{2}$, \\ TOMOHIKO WAKAYAMA ${ }^{3}$, SHOICHI ISEKI ${ }^{3}$ and TETSUO OHTA ${ }^{1}$ \\ ${ }^{1}$ Gastroenterologic Surgery, Division of Cancer Medicine, Department of Oncology, ${ }^{2}$ Center for Biomedical Research \\ and Education, ${ }^{3}$ Department of Histology and Embryology, Graduate School of Medical Science, \\ Kanazawa University, 13-1 Takara-machi, Kanazawa, Ishikawa 920-8641, Japan
}

Received February 22, 2012; Accepted April 2, 2012

DOI: 10.3892/ijo.2012.1499

\begin{abstract}
We previously reported that hepatic stellate cells (HSCs) activated by angiotensin II (AngII) facilitate stromal fibrosis and tumor progression in intrahepatic cholangiocarcinoma (ICC). AngII has been known as a growth factor which can promote epithelial-to-mesenchymal transition (EMT) in renal epithelial cells, alveolar epithelial cells and peritoneal mesothelial cells. However, in the past, the relationship between AngII and stromal cell-derived factor-1 (SDF-1) in the microenvironment around cancer and the role of AngII on EMT of cancer cells has not been reported in detail. SDF-1 and its specific receptor, CXCR4, are now receiving attention as a mechanism of cell progression and metastasis. In this study, we examined whether activated HSCs promote tumor fibrogenesis, tumor progression and distant metastasis by mediating EMT via the AngII/AngII type 1 receptor (AT-1) and the SDF-1/CXCR4 axis. Two human ICC cell lines and a human HSC line, LI-90, express CXCR4. Significantly higher concentration of SDF-1 $\alpha$ was released into the supernatant of LI-90 cells to which AngII had been added. SDF-1 $\alpha$ increased the proliferative activity of HSCs and enhanced the activation of HSCs as a growth factor. Furthermore, addition of SDF-1 $\alpha$ and AngII enhanced the increase of the migratory capability and vimentin expression, reduced E-cadherin expression, and translocated the expres-
\end{abstract}

Correspondence to: Dr Koichi Okamoto, Gastroenterologic Surgery, Division of Cancer Medicine, Department of Oncology, Graduate School of Medical Science, Kanazawa University, 13-1 Takara-machi, Kanazawa, Ishikawa 920-8641, Japan

E-mail: okamotok@staff.kanazawa-u.ac.jp

Key words: angiotensin II, hepatic stellate cell, stromal cell-derived factor-1, CXCR4, epithelial-to-mesenchymal transition sion of $\beta$-catenin into the nucleus and cytoplasm in ICC cells. Co-culture with HSCs also enhanced the migratory capability of ICC cells. These findings suggest that SDF-1 $\alpha$, released from activated HSCs and AngII, play important roles in cancer progression, tumor fibrogenesis, and migration in autocrine and paracrine fashion by mediating EMT. Our mechanistic findings may provide pivotal insights into the molecular mechanism of the AngII and SDF-1 $\alpha$-initiated signaling pathway that regulates fibrogenesis in cancerous stroma, tumor progression and metastasis of tumor cells expressing AT-1 and CXCR4.

\section{Introduction}

Intrahepatic cholangiocarcinoma (ICC) is highly fatal due to early invasion, rich fibrous stroma, and widespread metastasis. Current therapies for locally advanced or metastatic disease have little effect on the natural history of this malignancy. Understanding the molecular mechanisms underlying the progression of ICC may provide insights allowing the development of novel anti-neoplastic therapies. Chemokines are major regulators of cell migration and adhesion especially in the bone marrow microenvironment and are involved in the trafficking of lymphocytes and leukocytes during inflammation and immune responses. Recently, some evidences have been obtained about a role of the chemokine stromal cell-derived factor-1 (SDF-1) and its specific receptor, CXCR4, in cell cycle progression, migratory behavior, survival, and metastasis of tumor cells (1-4). Carcinoma-associated fibroblasts (CAFs) are thought to promote the growth of cancerous cells, angiogenesis, and stromal fibrosis by recruiting endothelial progenitor cells through the interaction between CXCR4 and SDF-1 released from CAFs $(2,5)$. In our previous study, we demonstrated that hepatic stellate cell (HSC) activation by angiotensin II (AngII) facilitated stromal fibrosis and tumor progression via an interaction with cancer cells in ICC tissues (6). Tumor progression and fibrosis are pivotal 
aspects of malignancy and several factors, including epidermal growth factor (EGF), transforming growth factor- $\beta$ (TGF- $\beta$ ), hepatocyte growth factor (HGF), vascular endothelial growth factor (VEGF), trypsinogen, AngII, and chemokines including SDF-1, are regarded as possibly being involved in cross-talk in tumor-stromal interactions (2-8).

The epithelial-to-mesenchymal transition (EMT) is a process initially observed in embryonic development in which cells lose epithelial characteristics and gain mesenchymal properties such as increased motility and the capacity for invasion $(9,10)$. Growth factors such as EGF, TGF- $\beta$, HGF and VEGF have been found to induce EMT (11-14). EMT is also a critical event that is occasionally observed during solid tumor progression, including invasion and metastasis, by which cancer cells acquire a more aggressive phenotype. Under these conditions, EMT is defined as the occurrence of a variable proportion of tumor cells up-regulating mesenchymal markers such as vimentin, and down-regulating epithelial markers such as E-cadherin and $\beta$-catenin $(14,15)$. Expressions of these EMT markers are induced by growth factor/receptor systems such as the TGF- $\beta$ / TGF- $\beta$ receptor system $(12,16)$. However, little is known about EMT induced by cytokines and chemokines, including AngII and SDF-1, despite abundant evidence of their involvement in the diverse cancer cells. AngII has been known as a growth factor which can occur EMT in renal epithelial cells, peritoneal mesothelial cells and alveolar epithelial cells (17-19). But in the past, the relationship between AngII and SDF-1 in the microenvironment around cancer tissues and the role of AngII on EMT of cancer cells has not been reported in detail.

We investigated whether HSCs activated by AngII in cancerous stromal tissues released SDF-1 into collagen-rich ICC tissues and hypothesized that the AngII/AngII type 1 receptor (AT-1) axis and SDF-1/CXCR4 axis activate the fibrogenesis in cancerous stroma, tumor invasion, and metastasis of ICC cells by mediating EMT via a synergistic interaction between cancer cells and CAFs including activated HSCs.

\section{Materials and methods}

Human tissue samples. The current study included 22 specimens of primary ICC (well to poorly-differentiated adenocarcinoma) that were surgically resected between 1998 and 2009. The average age of ICC patients was 64 years (range 35-84). The patients had stage I to IVB disease on the basis of the General Rules for the Clinical and Pathological Study of Primary Liver Cancer (20). Immediately following surgical removal, the tissue samples were frozen in liquid nitrogen and stored at $-80^{\circ} \mathrm{C}$ until the time of the assay for measuring AngII concentration. For immunohistochemical examination, the materials employed in this study, $20 \%$ formalin-fixed and paraffin-embedded specimens, were retrieved from the surgical pathology files of the Pathology Section of Kanazawa University Hospital, Kanazawa, Japan.

Measurement of angiotensin II in tissues. The determination of AngII concentration in ICC tissue was performed as follows. Briefly, tissue samples were homogenized at $4^{\circ} \mathrm{C}$ in saline containing $0.1 \mathrm{~N} \mathrm{HCl}$ and $5 \%$ urinastatin. The homogenate was sedimented at $10000 \mathrm{x}$ g for $30 \mathrm{~min}$ at $4^{\circ} \mathrm{C}$, and the supernatant was used for radioimmunoassay of AngII using the florisil method (florisil absorption and elution with acetone-hydrochloric acid solution) as described previously (21). This method is sensitive, specific and useful for routine clinical investigation. Parallel frozen tissue samples were homogenized in phosphatebuffered saline (PBS).

Cell culture. Two human ICC cell lines [HuCCT-1, obtained from the Cell Resource Center for Biochemical Research, Tohoku University, Sendai, Japan (22) and CCKS-1, obtained from the Department of Human Pathology, Kanazawa University Graduate School of Medicine, Kanazawa, Japan (23)], and a human hepatic stellate cell line [LI-90, obtained from the Human Science Cell Bank, Saitama, Japan (24)] were used. ICC cell lines were maintained at $37^{\circ} \mathrm{C}$ in a $5 \% \mathrm{CO}_{2}$ incubator and grown in RPMI-1640 medium supplemented with $2 \mathrm{mM}$ glutamine, $10 \%$ fetal bovine serum (FBS), $100 \mathrm{U} / 1$ penicillin and $100 \mu \mathrm{g} / \mathrm{ml}$ streptomycin. LI-90 cell lines were maintained at $37^{\circ} \mathrm{C}$ in a $5 \% \mathrm{CO}_{2}$ incubator and grown in Dulbecco's modified Eagle's medium (DMEM) supplemented with $2 \mathrm{mM}$ glutamine, $10 \% \mathrm{FBS}, 100 \mathrm{U} / 1$ penicillin and $100 \mu \mathrm{g} / \mathrm{ml}$ streptomycin.

Reagents and antibodies. AngII was used at concentrations of $1,10,100$ or $1000 \mathrm{nM}$. An active compound, telmisartan, which is a novel, long-acting, selective AT-1 receptor antagonist, was purchased from Sigma-Aldrich (St. Louis, MO, USA) and used at concentrations of 100 and $1000 \mathrm{nM}$, according to a previous report (6). Human recombinant SDF-1 $\alpha$ was purchased from Sigma-Aldrich and was used at concentrations of 1,10 or $100 \mathrm{ng} /$ $\mathrm{ml}$ according to a previous report (3). A CXCR4 antagonist, AMD3100 octahydrochloride hydrate, was purchased from Sigma-Aldrich and used at concentrations of 100 or $1000 \mathrm{ng} / \mathrm{ml}$. TGF- $\beta 1$ was purchased from Sigma-Aldrich and was used at a concentration of $10 \mathrm{ng} / \mathrm{ml}$. For primary antibodies, we obtained goat polyclonal SDF-1 antibody (Santa Cruz Biotechnology, CA, USA), goat polyclonal CXCR4 antibody (Santa Cruz), mouse monoclonal $\alpha$-smooth muscle actin ( $\alpha$-SMA) antibody (SigmaAldrich), mouse monoclonal $\beta$-actin antibody (Sigma-Aldrich), rabbit polyclonal glial fibrillary acidic protein (GFAP) antibody (Dako Cytomation, Glostrup, Denmark), mouse monoclonal E-cadherin antibody (Zymed Laboratories, CA, USA), mouse monoclonal $\beta$-catenin antibody (Santa Cruz), and mouse monoclonal vimentin antibody (Santa Cruz).

Immunohistochemistry. The expressions of SDF-1 and CXCR4 in resected ICC specimens were examined immunohistochemically using each primary antibody by LSAB (labeled streptavidin-biotin) method. To identify the antigen in tissues, deparaffinized sections were pretreated by autoclaving in $10 \%$ citric acid buffer ( $\mathrm{pH} 8.0$ ) at $120^{\circ} \mathrm{C}$ for $15 \mathrm{~min}$. After pretreatment with protein block serum (Dako Cytomation, Kyoto, Japan) for $10 \mathrm{~min}$ and in $2 \%$ skim milk for $20 \mathrm{~min}$ to block non-specific reactions, the sections were incubated with each primary antibody at $4^{\circ} \mathrm{C}$ overnight. After incubation, the slides were incubated with biotinylated rabbit anti-goat IgG (Vector Laboratories, CA, USA) for $1 \mathrm{~h}$ at room temperature and then with LSAB solution (LSAB kit, Dako) for $1 \mathrm{~h}$ at room temperature. The reaction products were developed in $0.02 \%$ 3,3'-diaminobenzidine tetrahydrochloride (DAB) solution containing $0.1 \% \mathrm{H}_{2} \mathrm{O}_{2}$. To identify the antigens of $\alpha$-SMA and GFAP in HSCs and E-cadherin, $\beta$-catenin and vimentin in 
ICC cells, we examined using HRP (horseradish peroxidase) method. The Envision+ polymer solution (HRP-conjugated secondary antibody, Dako Cytomation) was then applied for $1 \mathrm{~h}$ after primary antibody treatment. The reaction products were developed in DAB solution containing $0.1 \% \mathrm{H}_{2} \mathrm{O}_{2}$. The sections were then lightly counterstained with hematoxylin. The slides were examined under a fluorescence microscope (Olympus, Tokyo, Japan). Specimens were classified as positive when $>10 \%$ of cancer cells were stained. The intensity of each type of staining was graded as negative (no stain or weak positive) and positive (intermediate or strongly positive) microscopically.

Immunocytochemistry. The suspensions of cancer cells were seeded onto a Lab-Tek Chamber Slide System (2-well) (Nalge Nunc International, Rochester, NY, USA) and incubated for $24-48 \mathrm{~h}$ at $37^{\circ} \mathrm{C}$ in a humid atmosphere of $5 \% \mathrm{CO}_{2} / 95 \%$ air. The coverslips with cells were then fixed with methanol and acetone 1:1 (v/v). After pretreatment with protein blocking serum for 10 min to block non-specific binding, immunostaining for the expressions of CXCR4 in ICC cells was performed using the LSAB kit. Briefly, the slides were incubated with primary antibody (1:50) at $4^{\circ} \mathrm{C}$ overnight. After washing, biotinylated rabbit anti-goat IgG was applied for $1 \mathrm{~h}$ and then LSAB solution for $1 \mathrm{~h}$ at room temperature. The reaction products were visualized via a DAB reaction. The cells were then lightly counterstained with hematoxylin and examined under a fluorescence microscope.

Western blot analysis. Western blotting was performed as descrived previously (6). The polyvinylidene difluoride (PVDF) membrane were incubated for $2 \mathrm{~h}$ at room temperature with primary antibody against CXCR4 diluted 1:1000 with washing solution, followed by an HRP-conjugated anti-goat antibody diluted 1:5000 with washing solution. Chemiluminescence was detected with the ECL Plus Western Blotting Detection System (GE Healthcare Bioscience, Japan). We also used anti-SDF-1 antibody for Western blotting to measure the up- or downregulation of SDF-1 expressions in LI-90 incubated in medium to which AngII (100 nM) or TGF- $\beta 1(10 \mathrm{ng} / \mathrm{ml})$ added.

Extraction of RNA and reverse transcriptase polymerase chain reaction (RT-PCR) for SDF-1, CXCR4 and GAPDH $m R N A$. After the isolation of mRNA using TRI Reagent (Sigma-Aldrich) and synthesize first-strand cDNA using RNeasy Mini Kit (Qiagen, USA) and QIA shredder (Qiagen), PCR for SDF-1, CXCR4 and GAPDH was performed with a TaqMan PCR Kit (Takara, Japan), according to the manufacturer's instructions. The SDF-1 forward primer sequence was 5'-CCGCGCTCTGCCTCAGCGACGGGAAG-3' and the reverse was 5'-CTTGTTTAAAGCTTTCTCCAGGTACT-3' (this pair generated a 227-bp fragment). The CXCR4 forward primer sequence was 5'-TTCTACCCCAATGACTTGTG-3' and the reverse was 5'-ATGTAGTAAGGCAGCCAACA-3' (this pair generated a 260-bp fragment). The GAPDH oligonucleotide primer set (forward 5'-ACCACAGTCCATGCCATCAC-3', reverse 5'-TCCACCACCCTGTTGCTGTA-3'; this pair generated a 452-bp fragment) was used as an internal standard. PCR was performed for 35 cycles (denaturation at $98^{\circ} \mathrm{C}$ for $15 \mathrm{sec}$, annealing at $58^{\circ} \mathrm{C}$ for $30 \mathrm{sec}$, and extension at $74^{\circ} \mathrm{C}$ for $45 \mathrm{sec}$ ). After PCR, $5 \mu \mathrm{l}$ samples of the products were subjected to
$2.0 \%$ agarose gel electrophoresis and stained with ethidium bromide.

Enzyme-linked immunosorbent assay (ELISA) of SDF-1 $\alpha$. The baseline levels of SDF-1 $\alpha$ production by LI-90 cells treated with and without different concentrations (0.1-100 ng/ml) of AngII were determined. LI-90 cells were seeded onto $6-\mathrm{cm}$ dishes at a density of $1 \times 10^{5} / \mathrm{ml}$ and cultured for $24 \mathrm{~h}$. Pretreatment with an antagonist of AngII, telmisartan (1000 nM), was carried out for 30-60 min before the addition of AngII. After the medium had been replaced with fresh medium, the cells were cultured for another $48 \mathrm{~h}$. The concentration of SDF-1 $\alpha$ in the supernatant was measured by ELISA using a human SDF-1 $\alpha$ antibody and an enzyme immunoassay kit (R\&D Systems), according to the manufacturer's instructions.

Cell proliferation assay. The proliferative effect of SDF-1 $\alpha$ on HSCs was quantified using an MTT colorimetric assay with Cell Proliferation Kit I (Roche, Basel, Switzerland), as descrived previously (6). In brief, LI-90 cells $\left(5 \times 10^{3}\right.$ cells/well) was grown in 96-well flat-bottom microtiter plates in $100 \mu \mathrm{l}$ of medium including $1 \% \mathrm{FBS}$ and incubated for $48-96 \mathrm{~h}$ at $37^{\circ} \mathrm{C}$ in a humidified atmosphere (e.g., $\left.37^{\circ} \mathrm{C}, 5 \% \mathrm{CO}_{2}\right)$. The medium contained different concentrations $(0.1-100 \mathrm{ng} / \mathrm{ml})$ of SDF-1 $\alpha$. In some experiments, AMD3100, an antagonist of CXCR4, was added to the SDF- $1 \alpha$ treatment to assure that the proliferative effect caused by SDF-1 $\alpha$ occurred via the CXCR4 receptor. After the incubation period, $10 \mu \mathrm{l}$ of the MTT labeling reagent (final concentration $0.5 \mathrm{mg} / \mathrm{ml}$ ) were added to each well, the microplate was incubated for $4 \mathrm{~h}$ in a humidified atmosphere (e.g., $37^{\circ} \mathrm{C}, 5 \% \mathrm{CO}_{2}$ ) and then $100 \mu \mathrm{l}$ of the solubilization solution were added to each well. We allowed the plate to stand overnight in the incubator in a humidified atmosphere (e.g., $37^{\circ} \mathrm{C}, 5 \% \mathrm{CO}_{2}$ ), then checked for complete solubilization of the purple formazan crystals, and measured the spectrophotometric absorbance value of the samples using a microplate reader. The wavelength for measuring absorbance of the formazan product is $595 \mathrm{~nm}$. The experiments were repeated in triplicate wells. Cell viability was calculated as follows: Cell number (\% of control $)=($ absorbance of experimental wells $) /($ absorbance of control wells) x $100(\%)$.

Fluorescent immunocytochemistry. LI-90 cells were grown on a Lab-Tek Chamber Slide System to 40\%-60\% confluence, serumdeprived overnight (DMEM + 1\% FBS), and then treated with $100 \mathrm{ng} / \mathrm{ml}$ of SDF- $1 \alpha$ or $10 \mathrm{ng} / \mathrm{ml}$ of TGF- $\beta 1$ in the presence or absence of pretreatment for $1 \mathrm{~h}$ with $1000 \mathrm{ng} / \mathrm{ml}$ of AMD3100. CCKS-1 cells were seeded and grown on the Lab-Tek Chamber Slide System to $40 \%-50 \%$ confluence, serum-deprived overnight (RPMI-1640 + 1\% FBS), and then treated with or without $100 \mathrm{ng} / \mathrm{ml}$ of SDF- $1 \alpha$ in the presence or absence of pretreatment for $1 \mathrm{~h}$ with $1000 \mathrm{ng} / \mathrm{ml}$ of AMD3100. Cells were fixed with $3.7 \%$ formalin for $10 \mathrm{~min}$ at room temperature. After washing the cells with PBS, non-specific binding was blocked with Protein Blocking Reagent (Dako) for $1 \mathrm{~h}$ at room temperature. LI-90 cells were incubated with the primary antibodies ( $\alpha$-SMA and GFAP) and ICC cells were incubated with each primary antibody (E-cadherin, $\beta$-catenin, or vimentin) overnight at $4^{\circ} \mathrm{C}$. Slides were then washed and incubated with the appropriate Alexa Fluor 488 and 592 nm phalloidin (Molecular Probes, Inc., 


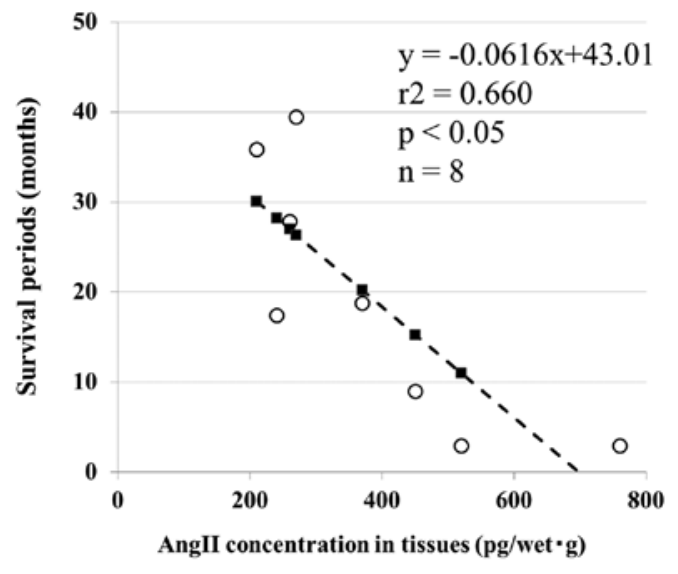

Figure 1. Correlation between AngII concentration and survival period. The dotted lines indicate the value of each AngII concentration of initial resected 8 ICC tissues and their survival periods. Linear regression analysis showed a significant colleration between AngII concentration of resected ICC tissues and survival periods after resection.

Eugene, OR, USA)-conjugated specific secondary antibodies for double staining for $1 \mathrm{~h}$ at room temperature. Cells were then incubated with Hoechst 33258 for nuclear staining for 5 min and mounted with propyl gallate containing phenylenediamine under glass coverslips. Cells were then visualized for immunofluorescence with a laser scanning Olympus microscope at x10, x20 and x40 magnification or a Confocal LSM510 microscope
(Carl Zeiss Microimaging, Inc., Thornwood, NY, USA) at x63 magnification.

In vitro migration assays of cultured ICC cells. The migratory capabilities of both cultured ICC cell lines were assayed using a BD BioCoat Matrigel invasion chamber (24-well plate, $8-\mu \mathrm{m}$ pore) (BD Biosciences, Bedford, MA, USA). Matrigel invasion chamber used in this study is a growth factor-reduced type. Medium $(0.5 \mathrm{ml})$ containing $5 \times 10^{5}$ ICC cells was added to the upper chamber, and $0.5 \mathrm{ml}$ of either medium alone or medium supplemented with $0.1,1,10$ or $100 \mathrm{ng} / \mathrm{ml}$ of SDF- $1 \alpha$ was added to the lower chamber. AMD3100 was used at $1000 \mathrm{ng} / \mathrm{ml}$. For the migration assay of ICC cells co-cultured with LI-90 cells, medium $(0.5 \mu \mathrm{l})$ containing $5 \times 10^{5}$ ICC cells was added to the upper chamber, and $0.5 \mathrm{ml}$ of either medium alone or medium containing $4 \times 10^{4}$ LI-90 cells and $100 \mathrm{nM}$ of AngII, $100 \mathrm{ng} / \mathrm{ml}$ of SDF- $1 \alpha$, or $10 \mathrm{ng} / \mathrm{ml}$ of TGF- $\beta 1$ was added to the lower chamber with pretreatment of telmisartan or AMD3100. Chambers were incubated for $48 \mathrm{~h}$ at $37^{\circ} \mathrm{C}$ and $5 \% \mathrm{CO}_{2}$. ICC cells on the upper surface of the filter were removed using a cotton wool swab, and the cells that had migrated to the lower surface were stained using $1 \%$ toluidine blue after fixation with $100 \%$ methanol. The number of migratory cells was counted in 10 medium power fields (x20). Each experiment was conducted in triplicate. A migration index (the ratio of the number of migratory cells in an experimental group/the number of migratory cells in control groups with neither chemokines nor cytokines) was calculated in each experiment.
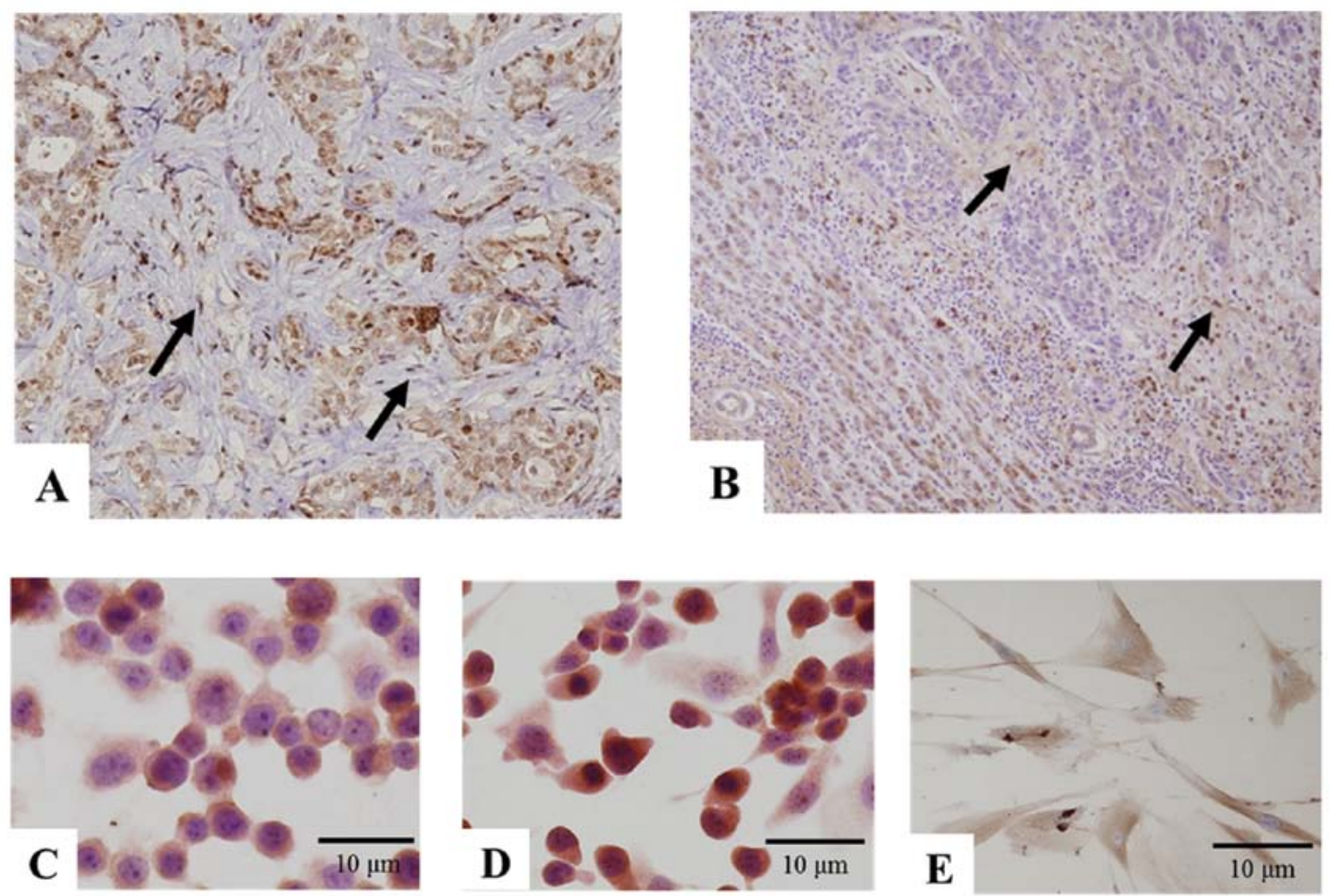

Figure 2. Expression of CXCR4 and SDF-1 in ICC tissues. ICC cells are homogeneously positive for CXCR4 (A). Lymphoid cells in the surrounding liver are also positive for CXCR4. In addition, fibroblast-like stroma cells (arrows) are clearly positive for CXCR4 in cancerous stroma tissues. Original magnification, x200. Fibroblast-like stroma cells (arrows) are clearly positive for SDF-1 in ICC tissues (B). ICC cells are also weakly and homogeneously positive for SDF-1. Immunostaining for CXCR4 and SDF-1 counterstained by hematoxylin. Original magnification, x100. In immunocytochemistry for CXCR4 in ICC cells and HSCs, CXCR4 expression was intense in HuCCT-1 (C), CCKS-1 (D) and LI-90 cells (E). CXCR4 immunoreactivity was diffusely evident in membranous and granular cytoplasmic patterns. 

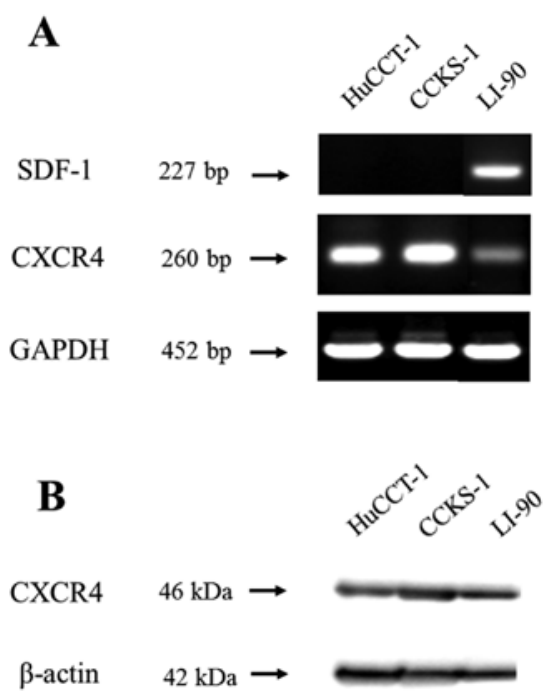

Figure 3. (A), In RT-PCR, SDF-1 expression at the mRNA level was not detected in HuCCT-1 and CCKS-1 cells, but was detected in LI-90 cells. (B), Western blot analysis demonstrated CXCR4 protein expression in all three cells. GAPDH and $\beta$-actin were used as internal controls.

Statistical analysis. Regression analysis was examineed for a correlation between AngII concentration in ICC tissues and survival periods. Statistical analyses were carried out using Student's unpaired t-test. Univariate analysis for survival was performed by using log-rank tests. $\mathrm{P}<0.05$ was considered statistically significant.

\section{Results}

Correlation between AngII concentration in ICC tissues and survival. The dotted lines indicate the value of each AngII concentration of initially resected 8 ICC tissues. There is a significant colleration between AngII concentration of resected ICC tissues and survival periods after resection. It is noteworthy that the higher concentration of AngII is, the longer the survival period of resected patient is. This result confirmed that the patients whose resected ICC tissues had higher AngII concentration had significantly poorer prognosis compared with the patients having lower AngII concentration (Fig. 1).

Expression of CXCR4 and SDF-1 in resected ICC specimens. Immunohistochemistry showed CXCR4 to be expressed in 12 of $16(75 \%)$ surgical specimens of human ICC. Immunoreactivity of CXCR4 was diffusely positive in the cytoplasm of cancer cells. In addition, fibroblast-like stromal cells were clearly positive for CXCR4 in the cancerous stroma (Fig. 2A, arrows). In the surrounding liver, hepatocytes were weakly positive and lymphoid cells were positive for CXCR4 as well. ICC cells were weakly and diffusely positive for SDF-1 and fibroblastlike stromal cells were clearly positive for SDF-1 in cancerous stromal tissues (Fig. 2B, arrows). In the surrounding liver, a few fibroblasts, hepatocytes, and bile ducts were positive for SDF-1.

CXCR4 and SDF-1 expressions in human ICC and HSC cells. Immunoreactivity of CXCR4 receptor was evident in membranous and granular cytoplasmic patterns in HuCCT-1, CCKS-1 and LI-90 cells (Fig. 2C-E). CXCR4 expression at the mRNA level was detected in all three cell lines by RT-PCR (208 bp, Fig. 3A). LI-90 cells expressed SDF-1 mRNA and protein constitutively, whereas no ICC cells in either cell line expressed SDF-1 mRNA (228 bp, Fig. 3A). Western blot analysis demonstrated CXCR4 protein expression in all three cell lines $(46 \mathrm{kDa}$, Fig. 3B).

SDF-1 $\alpha$ released from activated HSCs induced cell proliferation at autocrine fashion. LI-90 cells were incubated with $100 \mathrm{nM}$ AngII and $10 \mathrm{ng} / \mathrm{ml}$ TGF- $\beta 1$. Western blotting showed that, SDF-1 $\alpha$ protein was more clearly detectable in cultured LI-90 cells with $100 \mathrm{nM}$ AngII or $10 \mathrm{ng} / \mathrm{ml}$ TGF- $\beta 1$ treatment than in untreated cells (Fig. 4A). ELISA showed the SDF-1 $\alpha$ level in the supernatant of untreated cultured LI-90 cells to be $16.67 \pm 5.3 \mathrm{pg} / \mathrm{ml}$. The addition of $1-1000 \mathrm{nM}$ of AngII in the supernatant of the cultured LI-90 cells induced a dose-depen-
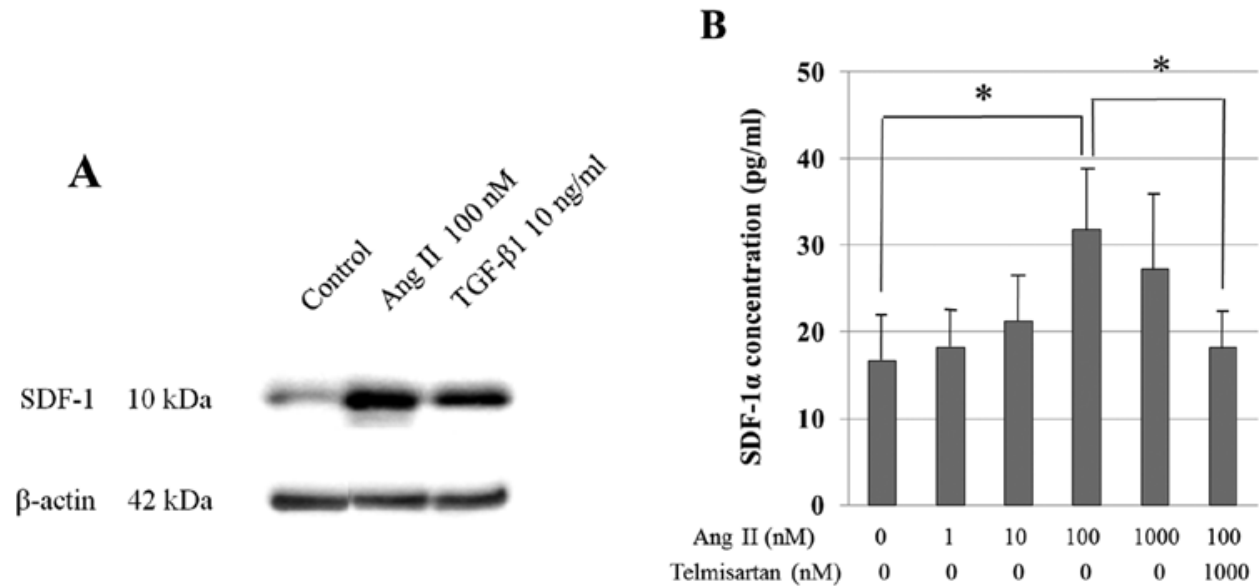

Figure 4. (A), Western blotting shows that SDF-1 $\alpha$ protein in cultured LI-90 cells was weakly detected without treatment, but was clearly detected by incubating with $100 \mathrm{nM}$ AngII or $10 \mathrm{ng} / \mathrm{ml}$ TGF- $\beta 1$. (B), ELISA shows that SDF-1 $\alpha$ protein level in the supernatant of the cultured LI-90 added $100 \mathrm{nM}$ AngII significantly increased compared with untreated cells. The pretreatment with $1000 \mathrm{nM}$ telmisartan in the supernatant of the cultured LI-90 added $100 \mathrm{nM}$ AngII significantly inhibited the increase of SDF-1 $\alpha$ protein level. Results are the means \pm SD of triplicate experiments. " $\mathrm{P}<0.05$ compared with control (untreated) cells by unpaired t-test. 


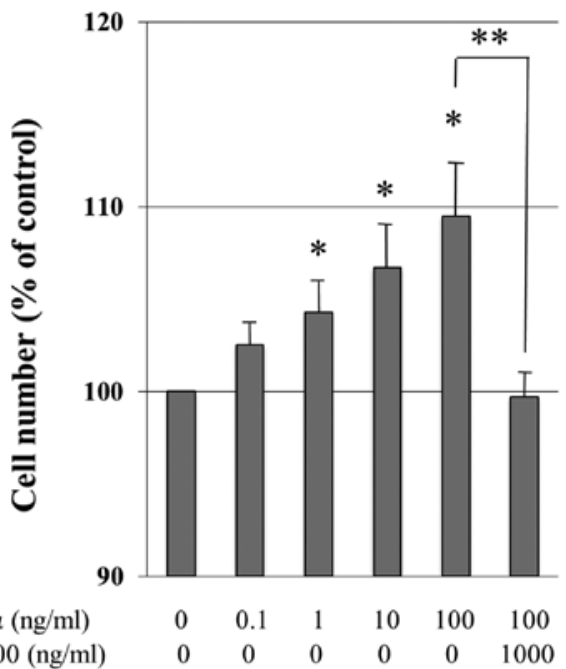

Figure 5. Proliferative effects of SDF-1 $\alpha$ in HSCs. LI-90 cells treated with each concentration of SDF-1 $\alpha(0.1-100 \mathrm{ng} / \mathrm{ml})$ dose-dependently increased in number at concentrations of SDF- $1 \alpha$ from 1 to $100 \mathrm{ng} / \mathrm{ml}$. AMD3100 completely inhibited the $100 \mathrm{ng} / \mathrm{ml}$ SDF-1 $\alpha$-induced proliferative response at a concentration of $1000 \mathrm{ng} / \mathrm{ml}$. Results are the means \pm SD of triplicate experiments. ${ }^{*} \mathrm{P}<0.05$ versus control. ${ }^{* *} \mathrm{P}<0.05$ versus $100 \mathrm{ng} / \mathrm{ml}$ SDF- $1 \alpha$.

dent increase in SDF-1 $\alpha$ protein level. The addition of $100 \mathrm{nM}$ AngII to the supernatant of cultured LI-90 cells induced a significant increase in SDF-1 $\alpha$ as compared with untreated cells $(31.82 \pm 5.3 \mathrm{pg} / \mathrm{ml})$ and pretreatment with $1000 \mathrm{nM}$ telmisartan significantly inhibited the increase in the release of SDF-1 $\alpha$ protein $(18.19 \pm 4.5 \mathrm{pg} / \mathrm{ml})$ (Fig. 4B). These results indicated that SDF-1 $\alpha$ released from LI-90 cells into the supernatant was down-regulated by antagonizing AT-1 receptor. To examine the proliferative effect of SDF-1 $\alpha$ on HSCs, LI-90 cells were treated with SDF-1 $\alpha$ and the proliferative effects were quantified by MTT assay. After a 48-h incubation, the proliferation of LI-90 cells was dose-dependently increased by SDF-1 $\alpha$ at concentrations from 1 to $100 \mathrm{ng} / \mathrm{ml}$. AMD3100 significantly inhibited the $100 \mathrm{ng} / \mathrm{ml} \mathrm{SDF}-1 \alpha$-induced proliferative effect at a concentration of $1000 \mathrm{ng} / \mathrm{ml}$ (Fig. 5).

SDF-1 $\alpha$ enhanced the activation of HSCs. GFAP is known to be expressed in quiescent or partially activated HSCs as a cellspecific marker of HSCs and $\alpha$-SMA is known as a cell-specific marker of activated HSCs and myofibroblasts (25). When the quiescent HSCs were stimulated by attractants, the transdifferentiation of HSCs into myofibroblasts and the expression of $\alpha$-SMA in the cytoplasm were enhanced. In untreated HSCs, GFAP expression was ubiquitous in the cytoplasm of nearly all cells, while only partial $\alpha$-SMA expression was seen in the cytoplasm. Fluorescent immunocytochemistry showed that adding $100 \mathrm{ng} / \mathrm{ml}$ SDF-1 $\alpha$ to LI-90 cells increased the number of $\alpha$-SMA-positive LI-90 cells as compared with control cells (Fig. 6A and B). AMD3100 at $1000 \mathrm{ng} / \mathrm{ml}$ inhibited the activa-
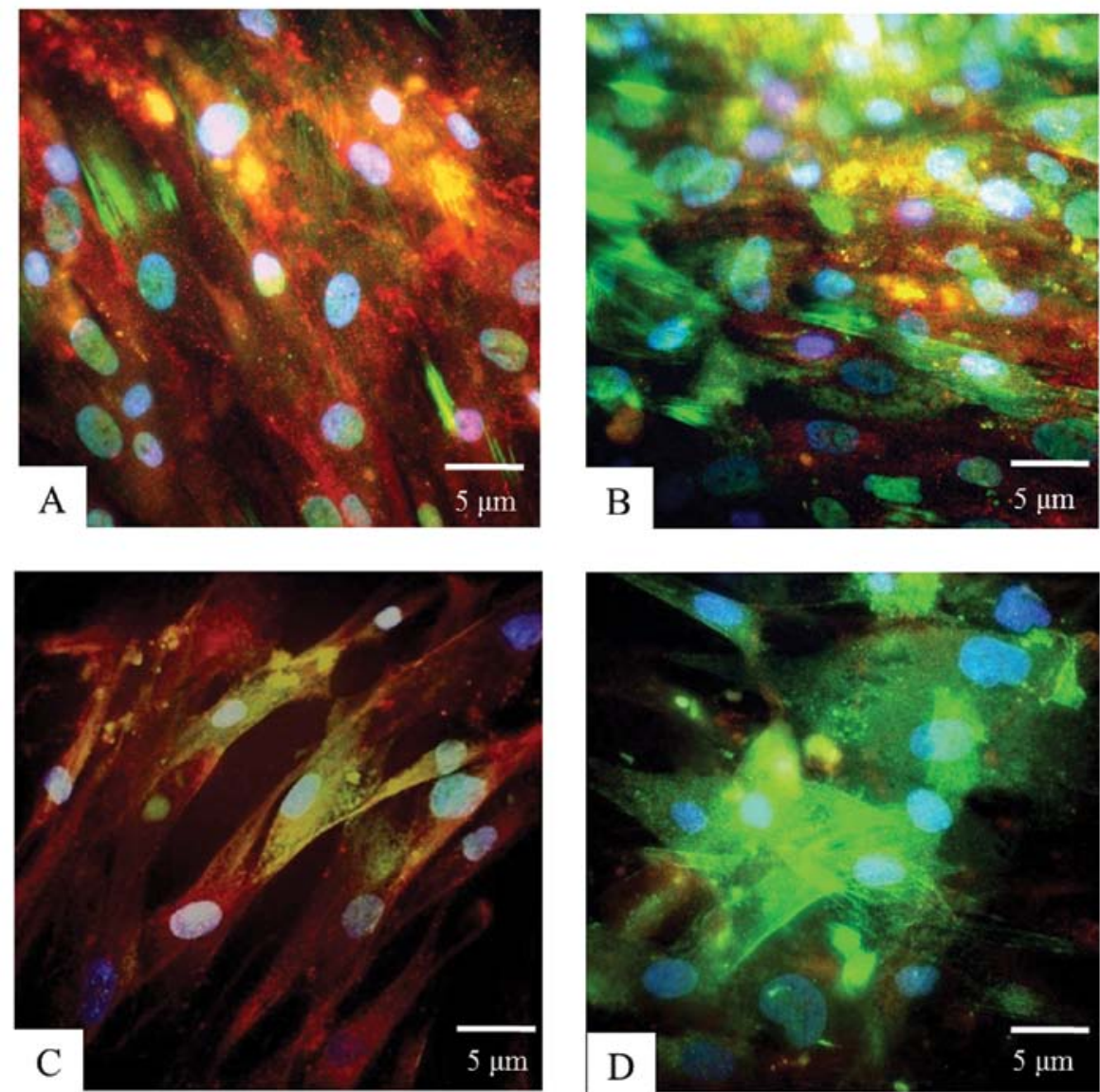

Figure 6. Fluorescent immunocytochemistry of SDF-1 $\alpha$-induced activation of LI-90 cells (green, $\alpha$-SMA; red, GFAP; blue, nuclei). When LI- 90 cells were added to SDF-1 $\alpha$, the number of $\alpha$-SMA-positive cells increased [(A), control cells; (B), $100 \mathrm{ng} / \mathrm{ml}$ SDF-1 $\alpha$-treated cells]. AMD3100 inhibited the activation of cells [(C), SDF-1 $\alpha 100 \mathrm{ng} / \mathrm{ml}+$ AMD3100 $1000 \mathrm{ng} / \mathrm{ml}$ ]. Addition of $10 \mathrm{ng} / \mathrm{ml}$ TGF- $\beta 1$ also increased the number of $\alpha$-SMA-positive cells (D). 


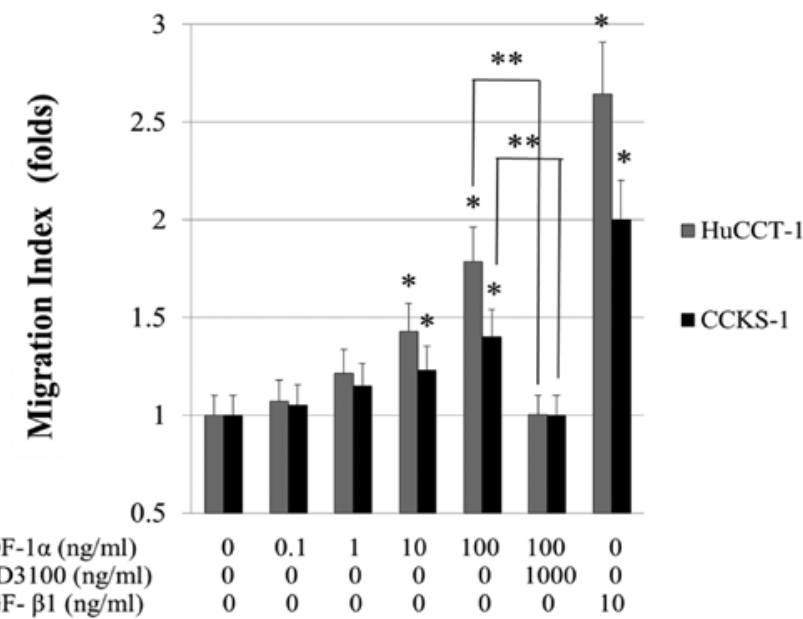

Figure 7. Migration of cultured ICC cells, increased when $0.1-100 \mathrm{ng} / \mathrm{m}$ SDF- $1 \alpha$ was added in the lower chamber (migration index of HuCCT-1 is 1.07-, 1.21-, 1.42-, 1.79-fold, respectively, compared with the control. Migration index of CCKS-1 is 1.05-, 1.15-, 1.23-, 1.4-fold, respectively, compared with the control). Migration capability of HuCCT-1 and CCKS-1 cells significantly increased when 10 and $100 \mathrm{ng} / \mathrm{ml}$ of SDF-1 $\alpha$ was added and the increase was inhibited when $1000 \mathrm{ng} / \mathrm{ml}$ AMD3100 was added to both cell lines. "P<0.05 versus control. ${ }^{* *} \mathrm{P}<0.05$ versus $100 \mathrm{ng} / \mathrm{ml} \mathrm{SDF}-1 \alpha$. The number of migrated cells was counted in 10 medium power fields $(\mathrm{x} 20)$. The data are provided as the mean \pm SD. Migration assay was performed three times in each experiment.

tion of LI-90 cells (Fig. 6C). Addition of $10 \mathrm{ng} / \mathrm{ml}$ TGF- $\beta 1$ to LI-90 cells induced the activation and the transformation into myofibroblasts (Fig. 6D).

Co-culture with LI-90 cells and the addition of SDF-1a enhanced migration capability of cultured ICC cells. When ICC cells were treated with $100 \mathrm{ng} / \mathrm{ml}$ of SDF- $1 \alpha$ in the lower chamber, the numbers of migrating HuCCT-1 and CCKS-1 cells significantly increased by 1.79- and 1.4-fold, respectively, as compared with control cells (Fig. 7). In contrast, more ICC cells migrated when LI-90 cells were co-cultured in the lower chamber; the migration index was 1.9-fold in HuCCT-1 and 1.7-fold in CCKS-1 as compared to the control. It is conceivable that LI-90 cells produce some factors promoting the migration of cultured ICC cells. When $1000 \mathrm{ng} / \mathrm{ml}$ of AMD3100 was added to the culture medium of both ICC cells co-cultured with LI-90 cells, migration of ICC cells was significantly suppressed to the control level (Fig. 8).

AngII and SDF-1 $\alpha$ enhanced the expression of EMT markers. Fluorescent immunocytochemistry revealed the expression of the epithelial adhesion molecule E-cadherin to be decreased $48 \mathrm{~h}$ after AngII or SDF-1 $\alpha$ treatment as compared with untreated HuCCT-1 and CCKS-1 cells. Furthermore, nuclear expression of $\beta$-catenin was increased $48 \mathrm{~h}$ after treatment with AngII or SDF-1 $\alpha$ under serum-starved conditions. Pretreatment of ICC cells with telmisartan or AMD3100 inhibited the decrease in E-cadherin expression, while $\beta$-catenin expression in the nucleus was decreased (green, E-cadherin; red, $\beta$-catenin; Fig. 9A). Conversely, an increase in the expression of the mesenchymal cell marker vimentin was observed at $48 \mathrm{~h}$ after AngII or SDF-1 $\alpha$ treatment. Furthermore, the increase in vimentin expression was also inhibited by adding $1000 \mathrm{nM}$ telmisartan

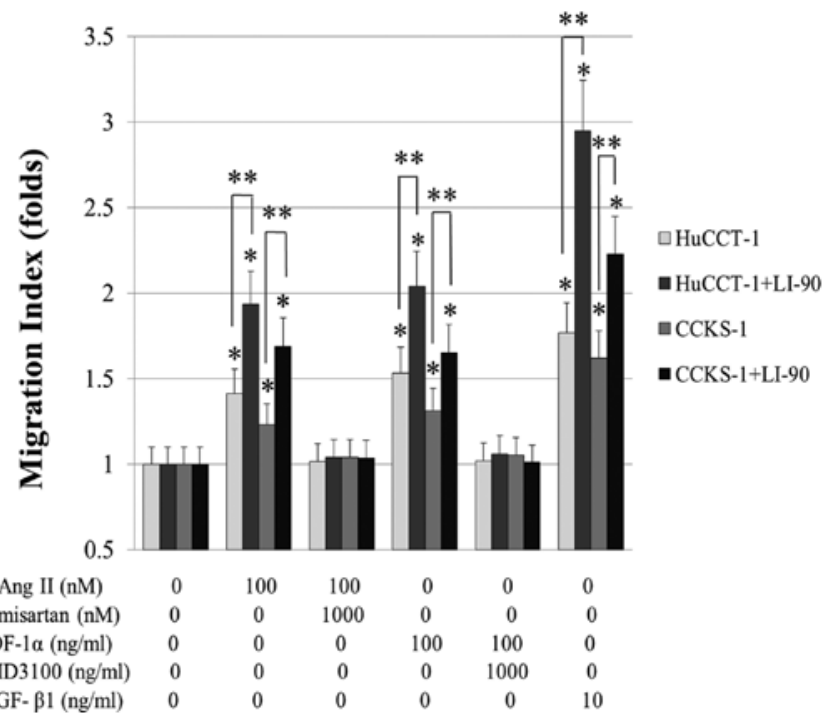

Figure 8. Migration of cultured ICC cells added with $100 \mathrm{nM}$ AngII increased in co-culture with LI-90 cells in the lower chamber for $48 \mathrm{~h}$ (migration of HuCCT-1 cells increased from 1.41- to 1.94-fold and that of CCKS-1 increased from 1.23- to 1.69-fold, respectively, compared with the control). The increase of migration capability of both ICC cells co-cultured with LI-90 cells significantly inhibited to the control level when $1000 \mathrm{nM}$ telmisartan was added. Migration of cultured ICC cells with added $100 \mathrm{ng} / \mathrm{ml} \mathrm{SDF-1} \alpha$ increased in coculture with LI-90 cells in the lower chamber for $48 \mathrm{~h}$ (migration of HuCCT-1 cells increased from 1.53- to 2.04-fold and that of CCKS-1 increased from 1.31- to 1.65-fold, respectively, compared with the control). The increase of migration capability of both ICC cells co-cultured with LI-90 cells significantly inhibited to the control level when $1000 \mathrm{ng} / \mathrm{ml}$ of AMD3100 was added to the culture medium. Migration of cultured ICC cells with added $10 \mathrm{ng} / \mathrm{ml}$ TGF- $\beta 1$ also increased in co-culture (migration of HuCCT- 1 cells increased from 1.77- to 2.95-fold and that of CCKS-1 increased from 1.62- to 2.23-fold, respectively, compared with the control). ${ }^{*} \mathrm{P}<0.05$ versus control cells. ${ }^{* *} \mathrm{P}<0.05$ with versus without co-culture with LI-90 cells.

or $1000 \mathrm{ng} / \mathrm{ml}$ AMD3100 to ICC cells treated with AngII or SDF-1 $\alpha$ (green, vimentin; blue, nucreus; Fig. 9B).

Correlation between the expression of each markers and the prognosis. The patients were visually divided into two groups by the intensity of each type of staining in immunohistochemistry. The correlations between the degree of the expression of each markers and the clinicopathological features with median survival time (MST) are shown in Table I. There was no significant difference on MST in the expression of $\beta$-catenin $(\mathrm{P}=0.059)$, CXCR4 ( $\mathrm{P}=0.429)$, and the stage of resected ICC patients $(\mathrm{P}=0.116)$. Significant differences on MST were observed in the expression of E-cadherin, vimentin, SDF-1, and histological differentiated type. Negative expression of E-cadherin $(\mathrm{P}=0.007)$, positive expression of vimentin $(\mathrm{P}=0.011)$ and SDF-1 $(\mathrm{P}=0.035)$, and poorly-differentiated type were found to have significantly poorer prognosis $(\mathrm{P}=0.044)$.

\section{Discussion}

In this study, we found that SDF-1, released from activated HSCs and AngII, contributes to stromal fibrosis, migration of cancer cells, and tumor progression in ICC tissues via EMT. It was suggested that AngII was associated with the synergistic effects on tumor fibrogenesis and tumor progression via SDF-1/ CXCR4 axis. Proliferation and activation of HSCs are the 
A

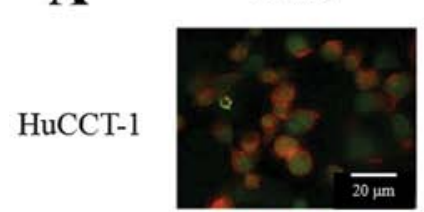

CCKS-1

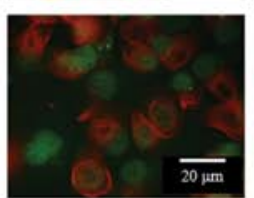

AngII
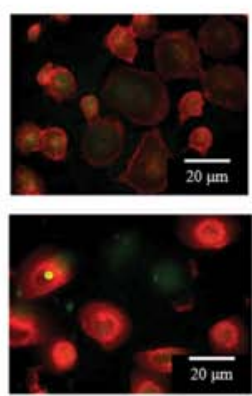

AngII + Telmisartan
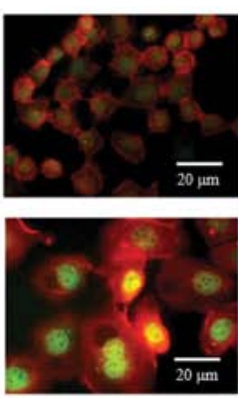

SDF-1 $\alpha$
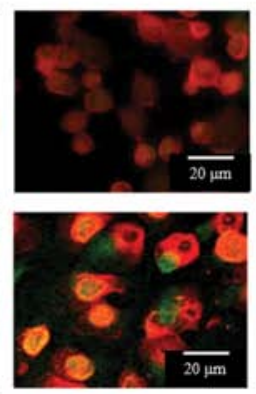
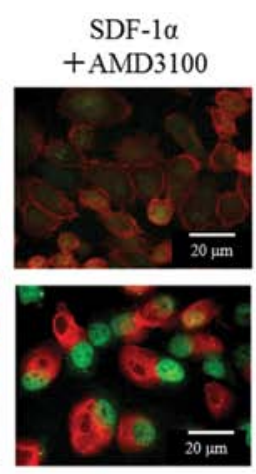

TGF- $\beta$
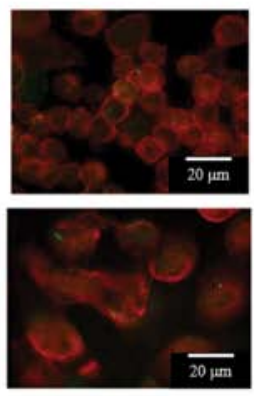

B

HuCCT-1
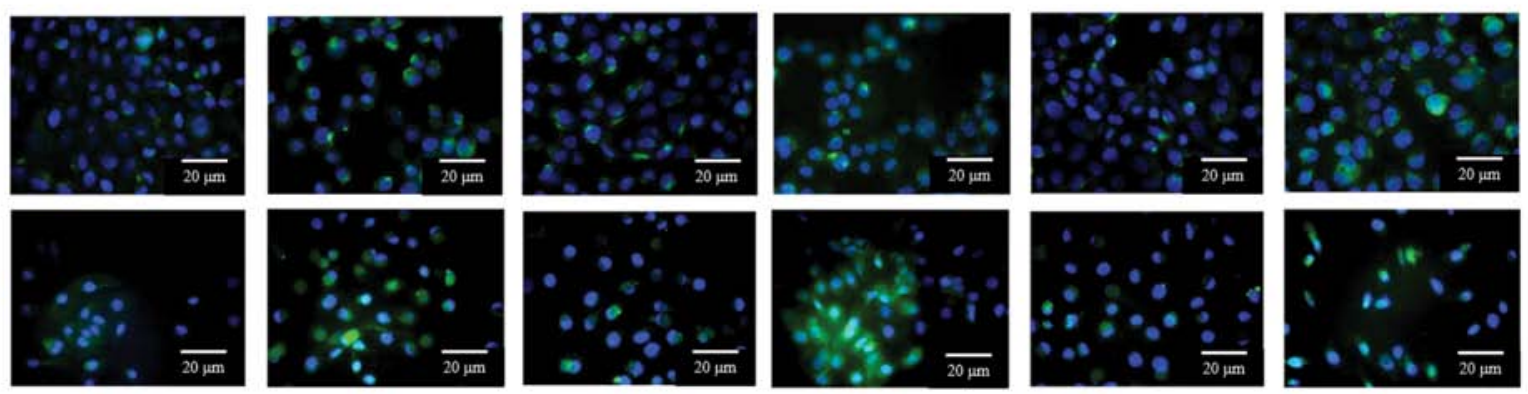

Figure 9. Fluorescent immunocytochemistry of AngII- or SDF-1 $\alpha$-induced changes in mesenchymal markers of ICC cells. Addition of AngII or SDF-1 $\alpha$ to ICC cells was found to disorganize, diffuse distribution in the cytoplasm, and down-regulate E-cadherin expression, whereas $\beta$-catenin translocated to the nucleus [(A): green, E-cadherin; red, $\beta$-catenin; blue, nuclei] and up-regulate vimentin [(B): green, vimentin; blue, nuclei]. Telmisartan inhibited the down-regulation of E-cadherin, translocation of $\beta$-catenin to the nucleus, and vimentin up-regulation in ICC cells treated with AngII. AMD3100 also inhibited the down-regulation of E-cadherin, translocation of $\beta$-catenin to the nucleus, and vimentin up-regulation in ICC cells treated with SDF- $1 \alpha$.

Table I. Correlation between the clinicopathological features and the expression of each markers with the prognosis of resected ICC patients. ${ }^{a}$

\begin{tabular}{llrrr}
\hline & & No. & $\begin{array}{r}\text { MST } \\
\text { (month) }\end{array}$ & P-value \\
\hline E-cadherin & Positive & 11 & 40 & 0.007 \\
& Negative & 11 & 9 & \\
$\beta$-catenin & Membranous & 9 & 24 & 0.059 \\
& Cytoplasmic or & 13 & 19 & \\
Vimentin & intranuclear & & & \\
& Positive & 10 & 17 & 0.011 \\
SDF-1 & Negative & 12 & 40 & \\
& Positive & 6 & 21 & 0.035 \\
CXCR4 & Negative & 10 & 40 & \\
& Positive & 6 & 24 & 0.429 \\
Histological type & Negative & 10 & 21 & \\
& well-mod & 16 & 30 & 0.044 \\
por & 6 & 9 & \\
& I-III & 10 & 30 & 0.116 \\
& IV & 12 & 10 & \\
\hline
\end{tabular}

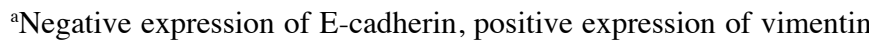
and SDF-1, and histologically poorly-differentiated type were found to have significantly poorer prognosis. dominant events in liver injury, inflammation and fibrosis that render cells responsive to cytokines and other local stimuli $(25,26)$. The current study demonstrated the enhancement of SDF-1 secretion from activated HSCs stimulated by AngII and the role of SDF-1 on the proliferation and activation of HSCs. Our previous report showed ICC tissues to have higher AngII concentrations than hepatocellular carcinoma and normal liver tissues, and we described the role of the AngII/AT-1 axis in cancer proliferation and cancerous fibrogenesis via the activation of HSCs (6). Furthermore, it was previously reported that HSCs may contribute to the desmoplastic reaction, invasiveness, and cell proliferation associated with primary and metastatic liver tumors $(8,27)$. It has also been reported that bone marrowderived fibroblasts contribute to tumor stromal reactions and tissue fibrosis and were recruited into cancer-induced stroma in late tumor stages (28). In terms of the role of chemokines on cancer cell proliferation, Ohira et al and Leelawat et al previously demonstrated that SDF-1 had no effect on the proliferative activity of cultured ICC cells $(3,29)$. We also examined the proliferative effect of SDF-1 $\alpha$ on HuCCT-1 and CCKS- 1 cells by MTT assay, and our result was almost identical to their results (data not shown). On the other hand, we previously reported that AngII had a significantly proliferative effect on ICC cells and AngII receptor blocker, telmisartan, treatment had a suppressive effect on cell proliferation (6).

EMT, in which tumor cells undergo loss of polarity and cellcell junctions and acquire a mesenchymal phenotype and the capabilities of invading the extracellular matrix and migrating to distant sites, has been a research focus with local invasion and 
metastasis being of particular interest $(30,31)$. Epithelial cancer cells have been known to transform to the cells with mesenchymal characteristics via stimulation with several cytokines or chemokines such as TGF- $\beta 1$, VEGF, HGF and SDF-1 (9-14). In the current study, we obtained ample evidence that CXCR4 activation by SDF-1 and AT-1 activation by AngII contribute to tumor progression by acting as a crucial mediator of EMT in vitro. We demonstrated that AngII and SDF-1 induced key events including down-regulation of epithelial adherens, such as E-cadherin and $\beta$-catenin, induction of mesenchymal marker, vimentin, and enhanced cell invasiveness and migration. Evidence of EMT in clinical tumor specimens has been established including loss or delocalization of junctional E-cadherin, switching to other cadherins (e.g., N-cadherin replaces E-cadherin), degradation of cell-to-cell adhesion, apicobasal polarity and tissue architecture alterations, pleiotropic cell shape, nuclear $\beta$-catenin, Snail or Slug expression, and the otherwise unexpected expressions of mesenchymal markers such as the intermediate filament protein vimentin $(9,32,33)$. But in the past, no evidence has been reported on the pivotal correlation between AngII in the cancer tissues and EMT of cancer cells.

AngII shares many cellular responses with TGF- $\beta$. In the kidney, ling, liver and vascular, AngII actively participates in renal fibrosis and in the parts mediated by TGF- $\beta$. Many studies have shown that AngII inhibitors diminish renal TGF- $\beta$ overproduction and signaling activation (26,34-41). A recent study found that AngII directly activates the Smad signaling system via AT-1 receptor in the kidney and induces the up-regulation of growth factors, extracellular matrix accumulation and EMT through the TGF- $\beta /$ Smad pathway $(36,37)$. The AT-1 signaling mechanisms are similar to those activated by cytokines, and include activation of protein kinases, e.g., the mitogen-activated protein kinase (MAPK) cascade and Rho-kinase (ROCK). Recent studies have demonstrated that the MAPK pathway regulates EMT via TGF- $\beta$ $(34,35)$. Previous investigations have shown that elucidating the molecular mechanisms involved in organ fibrosis might lead to improvements in current clinical treatments for fibrous diseases. Several studies have shown the MAPK pathway to be involved in EMT and fibrosis. AngII activates MAPK and through this pathway elicits many cellular responses. The specific inhibitors of all three MAPKs (p38, JNK and ERK1/2) prevented phenotypic conversion of cultured human epithelial cells into myofibroblasts and the loss of E-cadherin observed after 3 days of treatment with AngII, and markedly diminished inductions of the EMT markers vimentin and $\alpha$-SMA. The MAPK pathway is involved in EMT, fibrosis and cell migration caused by TGF- $\beta$ (34-41).

CXCR4 is widely expressed on hematopoietic, brain, lung, colon, heart, kidney and liver cells. CXCR4 has been suggested to contribute to the metastatic homing of cancer cells to various organs and tissues and seems to be an important pro-invasive factor. Cells expressing functional CXCR4 have been suggested to migrate and/or invade along SDF-1 gradients $(1,2)$. Previous reports demonstrated the role of CXCR4 signaling in local invasion and distant metastasis of breast cancer (42). SDF-1 is constitutively expressed in several organs including the lungs, liver, skeletal muscle, brain, kidneys, heart, skin and bone marrow and plays a role in the mobilization and recruitment of cells expressing CXCR4 to neoangiogenic niches supporting revascularization of ischemic tissue and tumor growth. Expression of CXCR4 on tumor cells, including those from several hematopoietic malignancies, implies that the SDF-1/ CXCR4 pathway may influence cancer biology and play an important role in directing the metastasis of tumor cells expressing CXCR4 to organs that express SDF-1 such as the lung, liver, bone or lymph nodes $(1,2,42,43)$. Interactions between CAFs including activated HSCs and cancer cells expressing CXCR4 may induce tumor progression, cancer fibrogenesis, tumor invasion, and cancer metastasis via EMT $(44,45)$, and may synergistically make ICC more highly malignant and more resistant to various therapies. The results shown in Table I are thought to be reasonable to support a correlation between the expression of SDF-1 and each EMT markers with the prognosis of ICC patients.

In conclusion, our results suggest that SDF-1 released from activated HSCs and AngII itself can contribute to stromal fibrosis and migration of cancer cells in collagen-rich liver tumors, such as ICC. A better understanding of the interplay between ICC cells and cancerous stroma will be important for developing strategies to improve tumor therapy that take into account the influences of the neoplastic microenvironment on tumor fibrosis, survival, and growth. Additionally, AngII receptor blockers and CXCR4 antagonists may be useful for treating collagen-rich tumors. Targeting the SDF-1 and AngII signaling pathways may be both a pivotal and an efficient strategy for treating high-grade neoplasms rich in cancerous stroma.

\section{References}

1. Teicher BA and Fricker SP: CXCL12 (SDF-1)/CXCR4 pathway in cancer. Clin Cancer Res 16: 2927-2931, 2010.

2. Orimo A, Gupta PB,Sgroi DC,Arenzana-Seisdedos F, Delaunay T, Naeem R, Carey VJ, Richardson AL and Weinberg RA: Stromal fibroblasts present in invasive human breast carcinomas promote tumor growth and angiogenesis through elevated SDF-1/CXCL12 secretion. Cell 121: 335-348, 2005.

3. Ohira S, Sasaki M, Harada K, Sato Y, Zen Y, Isse K, Kozaka K, Ishikawa A, Oda K, Nimura Y and Nakanuma Y: Possible regulation of migration of intrahepatic cholangiocarcinoma cells by interaction of CXCR4 expressed in carcinoma cells with tumor necrosis factor- $\alpha$ and stromal-derived factor- 1 released in stroma. Am J Pathol 168: 1155-1168, 2006.

4. Marchesi F, Monti P, Leone BE, Zerbi A, Vecchi A, Piemonti L, Mantovani A and Allavena P: Increased survival, proliferation, and migration in metastatic human pancreatic tumor cells expressing functional CXCR4. Cancer Res 64: 8420-8427, 2004.

5. Mishra PJ, Mishra PJ, Humeniuk R, Medina DJ, Alexe G, Mesirov JP, Ganesan S, Glod JW and Banerjee D: Carcinomaassociated fibroblast-like differentiation of human mesenchymal stem cells. Cancer Res 68: 4331-4339, 2008.

6. Okamoto K, Tajima H, Ohta T, Nakanuma S, Hayashi H, Nakagawara H, Ohishi I, Takamura H, Ninomiya I, Kitagawa H, Fushida S, Tani T, Fujimura T, Kayahara M, Harada S, Wakayama T and Iseki S: Angiotensin II induces tumor progression and fibrosis in intrahepatic cholangiocarcinoma through an interaction with hepatic stellate cells. Int J Oncol 37: 1251-1259, 2010.

7. Anandanadesan R, Gong Q, Chipitsyna G, Witkiewicz A, Yeo CJ and Arafat HA: Angiotensin II induces vascular endothelial growth factor in pancreatic cancer cells through an angiotensin II type 1 receptor and ERK1/2 signaling. J Gastrointest Surg 12: 57-66, 2008.

8. Amann T, Bataille F, Spruss T, Mühlbauer M, Gäbele E, Schölmerich J, Kiefer P, Bosserhoff AK and Hellerbrand C: Activated hepatic stellate cells promote tumorigenicity of hepatocellular carcinoma. Cancer Sci 100: 646-653, 2009.

9. Thiery JP: Epithelial-mesenchymal transitions in tumour progression. Nat Rev Cancer 2: 442-454, 2002. 
10. Buck E, Eyzaguirre A, Barr S, Thompson S, Sennello R, Young D, Iwata KK, Gibson NW, Cagnoni P and Haley JD: Loss of homotypic cell adhesion by epithelial-mesenchymal transition or mutation limits sensitivity to epidermal growth factor receptor inhibition. Mol Cancer Ther 6: 532-541, 2007.

11. Thompson EW, Newgreen DF and Tarin D: Carcinoma invasion and metastasis: a role for epithelial-mesenchymal transition? Cancer Res 65: 5991-5995, 2005.

12. Valcourt U, Kowanetz M, Niimi H, Heldin CH and Moustakas A: TGF-beta and the Smad signaling pathway support transcriptomic reprogramming during epithelial-mesenchymal cell transition. Mol Biol Cell 16: 1987-2002, 2005.

13. Elliott BE, Hung WL, Boag AH and Tuck AB: The role of hepatocyte growth factor (scatter factor) in epithelial mesenchymal transition and breast cancer. Can J Physiol Pharmacol 80: 91-102, 2002.

14. Yang AD, Camp ER, Fan F, Shen L, Gray MJ, Liu W, Somcio R, Bauer TW, Wu Y, Hicklin DJ and Ellis LM: Vascular endothelia growth factor receptor-1 activation mediates epithelial to mesenchymal transition in human pancreatic carcinoma cells. Cancer Res 66: 46-51, 2006.

15. Rosanò L, Spinella F, Di Castro V, Nicotra MR, Dedhar S, De Herreros AG, Natali PG and Bagnato A: Endothelin-1 promotes epithelial-to-mesenchymal transition in human ovarian cancer cells. Cancer Res 65: 11649-11657, 2005.

16. Andl CD, Fargnoli BB, Okawa T, Bowser M, Takaoka M, Nakagawa H, Klein-Szanto A, Hua X, Herlyn M and Rustgi AK: Coordinated functions of E-cadherin and transforming growth factor beta receptor II in vitro and in vivo. Cancer Res 66: 9878-9885, 2006.

17. Chen J, Chen JK and Harris RC: Angiotensin II induces epithelialto-mesenchymal transition in renal epithelial cells through ROS/ Src/Caveolin-mediated activation of an EGFR-ERK signaling pathway. Mol Cell Biol 32: 981-991, 2012.

18. Chang J, Jiang Z, Zhang H, Zhu H, Zhou SF and Yu X: NADPH oxidase-dependent formation of reactive oxygen species contributes to angiotensin II-induced epithelial-mesenchymal transition in rat peritoneal mesothelial cells. Int J Mol Med 28: 405-412, 2011.

19. Buckley ST, Medina C and Ehrhardt C: Differential susceptibility to epithelial-mesenchymal transition (EMT) of alveolar, bronchial and intestinal epithelial cells in vitro and the effect of angiotensin II receptor inhibition. Cell Tissue Res 342: 39-51, 2010.

20. Liver Cancer Study Group of Japan: The general rules for the clinical and pathological study of primary liver cancer. 5th edition. Kanehara, Tokyo, pp17-27, 2008.

21. Morimoto T, Aoyama M, Gotoh E and Shionoiri H: A method of radioimmunoassay of plasma angiotensin II using Florisil. Folia Endocrinoa Jpn 59: 215-229, 1983.

22. Miyagiwa M, Ichida T, Tokiwa T, Sato J and Sasaki H: A new human cholangiocellular carcinoma cell line (HuCC-T1) producing carbohydrate antigen 19/9 in serum-free medium. In Vitro Cell Dev Biol 25: 503-510, 1989.

23. Sugawara H, Yasoshima M, Katayanagi K, Kono N, Watanabe Y, Harada K and Nakanuma Y: Relationship between interleukin-6 and proliferation and differentiation in cholangiocarcinoma. Histopathology 33: 145-153, 1998.

24. Murakami K, Abe T, Miyazawa M, Yamaguchi M, Masuda T, Matsuura T, Nagamori S, Takeuchi K, Abe K and Kyogoku M: Establishment of a new human cell line, LI90, exhibiting characteristics of hepatic Ito (fat-storing) cells. Lab Invest 72: 731-739, 1995.

25. Salguero Palacios R, Roderfeld $M$, Hemmann $S$, Rath $T$, Atanasova S, Tschuschner A, Gressner OA, Weiskirchen R, Graf J and Roeb E: Activation of hepatic stellate cells is associated with cytokine expression in thioacetamide-induced hepatic fibrosis in mice. Lab Invest 88: 1192-1203, 2008.

26. Gressner AM and Weiskirchen R: Modern pathogenetic concepts of liver fibrosis suggest stellate cells and TGF- $\beta$ as major players and therapeutic targets. J Cell Mol Med 10: 76-99, 2006.

27. Tien YW, Wu YM, Lin WC, Lee HS and Lee PH: Pancreatic carcinoma cells stimulate proliferation and matrix synthesis of hepatic stellate cells. J Hepatol 51: 307-314, 2009.
28. Okabe H, Beppu T, Hayashi H, Horino K, Masuda T, Komori H, Ishikawa $\mathrm{S}$, Watanabe $\mathrm{M}$, Takamori $\mathrm{H}$, Iyama $\mathrm{K}$ and Baba $\mathrm{H}$ : Hepatic stellate cells may relate to progression of intrahepatic cholangiocarcinoma. Ann Surg Oncol 16: 2555-2564, 2009.

29. Leelawat K, Leelawat S, Narong S and Hongeng S: Roles of the MEK1/2 and AKT pathways in CXCL12/CXCR4 induced cholangiocarcinoma cell invasion. World J Gastroenterol 13: 1561-1568, 2007.

30. Gilles C and Thompson EW: The epithelial to mesenchymal transition and metastatic progression in carcinoma. Breast $\mathrm{J} 2$ : 83-96, 1996.

31. Ellenrieder V, Hendler SF, Boeck W, Seufferlein T, Menke A, Ruhland C, Adler G and Gress TM: Transforming growth factor beta1 treatment leads to an epithelial-mesenchymal transdifferentiation of pancreatic cancer cells requiring extracellular signal-regulated kinase 2 activation. Cancer Res 61: 4222-4228, 2001.

32. Peinado H, Portillo $\mathrm{F}$ and Cano A: Transcriptional regulation of cadherins during development and carcinogenesis. Int J Dev Biol 48: $365-375,2004$

33. Tomita K, van Bokhoven A, van Leenders GJ, Ruijter ET, Jansen CF, Bussemakers MJ and Schalken JA: Cadherin switching in human prostate cancer progression. Cancer Res 60: 3650-3654, 2000.

34. Rodrigues-Díez R, Carvajal-González G, Sánchez-López E, Rodríguez-Vita J, Rodrigues Díez R, Selgas R, Ortiz A, Egido J, Mezzano S and Ruiz-Ortega M: Pharmacological modulation of epithelial mesenchymal transition caused by angiotensin II. Role of ROCK and MAPK pathways. Pharm Res 25: 2447-2461, 2008.

35. Ruiz-Ortega M, Rupérez M, Esteban V, Rodríguez-Vita J, Sánchez-López E, Carvajal G and Egido J: Angiotensin II: a key factor in the inflammatory and fibrotic response in kidney diseases. Nephrol Dial Transplant 21: 16-20, 2006.

36. Carvajal G, Rodríguez-Vita J,Rodrigues-Díez R, Sánchez-López E, Rupérez M, Cartier C, Esteban V, Ortiz A, Egido J, Mezzano SA and Ruiz-Ortega M: Angiotensin II activates the Smad pathway during epithelial mesenchymal transdifferentiation. Kidney Int 74: 585-595, 2008.

37. Wolf G: Renal injury due to renin-angiotensin-aldosterone system activation of the transforming growth factor-beta pathway. Kidney Int 70: 1914-1919, 2006.

38. Bakin AV, Rinehart C, Tomlinson AK and Arteaga CL: p38 mitogen-activated protein kinase is required for TGFbeta mediated fibroblastic transdifferentiation and cell migration. J Cell Sci 115: 3193-3206, 2002.

39. Rupérez M, Lorenzo O, Blanco-Colio LM, Esteban V, Egido J and Ruiz-Ortega M: Connective tissue growth factor is a mediator of angiotensin II-induced fibrosis. Circulation 108: 1499-1505, 2003.

40. Moustakas A and Heldin CH: Non-Smad TGF-beta signals. J Cell Sci 118: 3573-3584, 2005.

41. Ruiz-Ortega M, Rodríguez-Vita J, Sanchez-Lopez E, Carvajal G and Egido J: TGF-beta signaling in vascular fibrosis. Cardiovasc Res 74: 196-206, 2007.

42. Lee BC, Lee TH, Avraham S and Avraham HK: Involvement of the chemokine receptor CXCR4 and its ligand stromal cellderived factor 1alpha in breast cancer cell migration through human brain microvascular endothelial cells. Mol Cancer Res 2: 327-338, 2004.

43. Onoue T, Uchida D, Begum NM, Tomizuka Y, Yoshida H and Sato M: Epithelial-mesenchymal transition induced by the stromal cell-derived factor-1/CXCR4 system in oral squamous cell carcinoma cells. Int J Oncol 29: 1133-1138, 2006.

44. Ishii G, Sangai T, Ito T, Hasebe T, Endoh Y, Sasaki H, Harigaya K and Ochiai A: In vivo and in vitro characterization of human fibroblasts recruited selectively into human cancer stroma. Int J Cancer 117: 212-220, 2005.

45. Kalluri R and Zeisberg M: Fibroblasts in cancer. Nat Rev Cancer 6: 392-401, 2006. 